\title{
Penerapan Model Pembelajaran Media Interaktif Menggunakan Software Articulate Storyline 3 pada Pembelajaran Lompat Jauh Siswa Kelas V
}

\author{
Didien Bachthiar Arrozi*, Arief Nur Wahyudi, Aba Sandi Prayoga \\ Pendidikan Jasmani Kesehatan dan Rekreasi, STKIP Modern Ngawi, Indonesia \\ *didin0495@gmail.com
}

\begin{abstract}
Abstrak
Penelitian ini bertujuan untuk meningkatkan hasil belajar lompat jauh dengan menggunakan Software Articulate Storyline 3 di SDIT Ummul Qurro Sambirejo Sragen kelas $\mathrm{V}$ mata pelajaran pendidikan jasmani kesehatan dan rekreasi materi lompat jauh. Metode penelitian ini adalah Penelitian Tindakan Kelas (PTK) yang dilakukan sebanyak satu siklus dengan jumlah 9 siswa. Penelitian ini dilaksanakan pada semester genap tahun ajaran 2020/2021. Teknik pengumpulan data yaitu melalui observasi, dan tes. Berdasarkan pelaksanaan tes awal aspek afektif mendapatkan nilai rata-rata 80 (tuntas), aspek kognitif rata-rata mendapat nilai 67 (tidak tuntas), dan aspek psikomotor 68 (tidak tuntas). Sehingga dilakukan siklus I untuk memperbaiki perolehan nilai pada aspek kognitif dan psikomotor. Setelah dilakukan siklus I pertemuan I dan II pembelajaran dengan menggunakan Software Articulate Storyline 3 maka diperoleh nilai rata-rata pada aspek kognitif 80 (tuntas), sedangkan aspek psikomotor memperoleh nilai rata-rata 80 (tuntas) sehingga secara umum menunjukan terjadi peningkatan yang baik dan tidak perlu berlanjut pada siklus II.
\end{abstract}

Kata kunci: articulate storyline 3, lompat jauh, media interaktif.

Dikirim: 31 Mei 2021

Direvisi: 10 Juni 2021

Diterima: 13 Juni 2021

\section{Identitas Artikel:}

Arrozi, D. B., Wahyudi, A.N., \& Prayoga, A. S. (2021). Penerapan Model Pembelajaran Media Interaktif Menggunakan Software Articulate Storyline 3 pada Pembelajaran Lompat Jauh Siswa Kelas V. Jurnal Ilmu Pendidikan (JIP) STKIP Kusuma Negara, 13(1), 44-50.

\section{PENDAHULUAN}

Pendidikan sangat penting untuk meningkatkan kualitas hidup setiap orang. Dalam dunia pendidikan kita diajarkan banyak hal mulai dari nilai kehidupan, pengetahuan umum, dan berbagai ilmu lainnya. Pendidikan adalah sebuah kegiatan dimana ada guru dan siswa yang saling berhubungan dalam penyampaian ilmu atau informasi (Muzakir, 2013). Pendidikan merupakan suatu proses pengubahan sikap dan tata perilaku seseorang dalam mendewasakan manusia melalui pengajaran dan pelatihan tertntu (Khasanah, Pramudibyanto \& Widuroyekti, 2020).

Namun untuk belakangan ini muncul wabah virus yang meresahkan dunia. Virus COVID-19 ini menyebabkan infeksi saluran pernafasan yang menyebar melalui sekresi pernafasan, kemudian hidung di dinding saluran pernafasan bagian atas, beberapa fakta menyebutkan bahwa virus COVID-19 ini menimbulkan banyak kematian (Risalah, Ibad, Maghfiroh, Azza, Cahyani \& Ulfayati, 2020). Pada kasus ini, pemerintah memberikan aturan untuk menghentikan aktivitas apa pun yang ada diluar yang dapat menimbulkan kerumunan dengan bertujuan agar tidak terjadi lebih banyak penularan virus COVID-19 dan melakukan aktivitas di rumah. Semua 
institusi tutup begitu juga dengan dunia pendidikan. Jadi beralih belajar di rumah menggunakan sistem online atau daring.

Teknologi informasi adalah satu-satunya jalan unutk melanjutkan proses belajar mengajar di sekolah. Teknilogi informasi sebuah alat yang dapat membantu bekerja dengan jalur komunikasi kecepatan tinggi yang berupa data, suara, dan video (Budiman, 2017). Teknologi informasi dapat membantu manusia dalam penyampaian sebuah informasi secara cepat dan dapat membantu membuat, mengubah, menyimpan, mengkomunikasikan dan menyebarkan sebuah informasi (Setiawan, 2018). Teknologi informasi dapat meningkatkan kualitas dan jangkauan yang luas apabila digunakan dengan baik untuk pendidikan dan sangat penting bagi kesejahteraan dalam pendidikan. Oleh karena itu teknologi informasi memberikan kemudahan dalam mengelola informasi.

Media pembelajaran sebuah alat yang dapat membantu kegiatan belajar mengajar dan juga dapat digunakan untuk menyalurkan pesan, menangkap, memproses, dan menyusun kembali informasi (Abidin, 2016). Media pembelajaran mempermudah siswa dalam memahami informasi dan juga dapat menarik perhatian siswa serta membantu meningkatkan konsentrasi dalam menangkap sebuah materi yang diberikan oleh guru (Alwi, 2017). Oleh karena itu peran media pembelajaran sangat penting dalam kegiatan proses belajar mengajar, selain itu guru juga harus mempunyai keterampilan dalam memilih dan menggunakan media tersebut.

Dalam situasi pandemi saat ini siswa diwajibkan belajar dari rumah oleh karena itu guru harus memberikan inovasi yang menarik dalam kegiatan belajar mengajar. Inovasi merupakan sebuah pengembangan dan gagasan-gasan baru yang dapat diterima oleh seseorang atau kelompok tertentu untuk digunakan ataupun di adopsi (Kuswanto \& Radiansah, 2018). Di SDIT Ummul Qurro Sambirejo Sragen pada pembelajaran pendidikan jasmani olahraga dan kesehatan kelas V materi lompat jauh penyampain sebauh materi masih tergolong monoton dan kurang kreatif, pada saat pembelajaran guru hanya memberikan materi berupa foto melalui Whatsapp disamping itu sebagian besar guru juga menggunakan model pembelajaran yang sama. Penggunaan media Whatsapp pada penyampaian materi masih kurang jelas, karena siswa harus membaca dan menyimpulkan materi sendiri. Terlebih siswa sekolah dasar harus jelas pada saat pemberian materi.

Pada era modern saat ini banyak sekali software yang menarik yang dapat digunakan oleh guru pada saat pembelajaran berlangsung. Sayangnya tidak semua guru mengetahui dan dapat menggunakan semua software yang ada. Tujuan dari penelitian ini yaitu melihat perkembangan belajar siswa dalam menggunakan software Articulate Storyline 3. Articulate Storyline 3 adalah perangkat lunak yang dapat digunakan untuk membuat presentasi yang memiliki fungsi sama dengan power point dengan kelebihan yang berbeda, komprehensif, dan kreatif (Salwani \& Ariani, 2021). Software Artiulate Storyline 3 dirasa pas dalam penyajian materi, karena pada saat penyampaian materi yang disampaikan adalah poin-poin terpenting dalam pembelajaran dan didalam Articulate Storyline 3 dapat menampilkan video, terlebih pembelajaran Pendidikan Jasmani Olahraga dan Kesehatan (PJOK) materi lompat jauh bannyak macam-macam gaya sehingga siswa tidak hanya mampu menangkap materi dari aspek pengetahuan namun juga aspek psikomotor. 


\section{METODE PENELITIAN}

Jenis penelitian ini adalah Penelitian Tindakan Kelas (PTK) yang dilaksanakan dengan satu siklus dua kali pertemuan untuk melihat peningkatan hasil belajar siswa dalam mengikuti pembelajaran PJOK materi lompat jauh melalui penerapan Software Articulate Storyline 3.

Penelitian ini dilakukan di SDIT Ummul Qurro Sambirejo Sragen. Waktu penelitian ini dilakukan selama 2 bulan yaitu 18 Januari 2021 sampai dengan 18 Februari 2021. Subjek penelitian ini adalah siswa kelas V dengan jumlah 9 siswa semester genap tahun ajaran 2020/2021.

Teknik pengumpulan data dilakukan melalui Tes dan Observasi. Untuk lebih jelasnya dapat dilihat pada Tabel 1 .

Tabel 1. Teknik Pengumpulan Data

\begin{tabular}{|c|c|c|c|c|}
\hline $\begin{array}{c}\text { Sumber } \\
\text { Data }\end{array}$ & $\begin{array}{l}\text { Jenis } \\
\text { Data }\end{array}$ & \multicolumn{3}{|r|}{ Teknik Pengumpulan Data } \\
\hline \multirow{4}{*}{ Siswa } & \multirow{4}{*}{$\begin{array}{l}\text { Hasil } \\
\text { Belajar } \\
\text { Siswa }\end{array}$} & No & Aspek & Instrument \\
\hline & & 1 & Afektif & $\begin{array}{l}\text { Observasi: melihat perilaku siswa } \\
\text { selama pembelajaran berlangsung. } \\
\text { keaktifan, keseriusan, disiplin, dan } \\
\text { bertanggungjawab. } \\
\text { menyiapkan lembar penilaian }\end{array}$ \\
\hline & & 2 & Kognitif & $\begin{array}{l}\text { Pemberian soal tes, } 15 \text { butir, pilihan } \\
\text { ganda. Indikator gaya lompat jauh dan } \\
\text { peraturan lompat jauh. Soal diberikan } \\
\text { langsung di software tersebut. }\end{array}$ \\
\hline & & 3 & Psikomotor & $\begin{array}{l}\text { Memberikan video materi didalam } \\
\text { Software Articulate Storyline } 3 \text { macam- } \\
\text { macam gaya lompat jauh. Dan } \\
\text { diberikan soal }\end{array}$ \\
\hline
\end{tabular}

Untuk keberhasilan sebuah penelitian ini apabila mendapatkan skor 70 dengan kategori "Baik" sesuai dengan Kriteria Ketuntasan Minimum (KKM) yaitu 70 yang meliputi aspek Afektif, Kognitif, dan Psikomotor. Untuk tercapainya nilai pada pembelajaran tersebut dapat dilihat pada Tabel 2.

Tabel 2. Rentang Skor Penilaian

\begin{tabular}{cccccc}
\hline \multirow{2}{*}{ No } & \multicolumn{3}{c}{ Aspek Penilaian } & \multirow{2}{*}{ Predikat } & \multirow{2}{*}{ Kriteria } \\
\cline { 2 - 4 } & Afektif & Kognitif & Psikomotor & & \\
\hline 1 & $81-100$ & $81-100$ & $81-100$ & Sangat Baik & Tuntas \\
2 & $70-80$ & $70-80$ & $70-80$ & Baik & Tuntas \\
3 & $51-69$ & $51-69$ & $51-69$ & Cukup & Tidak Tuntas \\
4 & $<50$ & $<50$ & $<50$ & Kurang & Tidak Tuntas \\
\hline
\end{tabular}

\section{HASIL PENELITIAN}

\section{Hasil Observasi Tes Awal}

Pelaksanaan direncanakan pada siklus I pertemuan I dan II. Pada siklus I pertemuan II menunjukkan peningkatan yang siginifikan pada pembelajaran lompat jauh. 
Penelitian diawali dengan observasi pada awal penelitian kemudian dilakukan tindakan, pelaksanaan, pengamatan dan yang terakhir adalah refleksi.

Observasi tes awal dilakukan untuk mengetahui sebarapa paham siswa menyerap informasi pembelajaran yang diberikan oleh guru menggunakan whatsapp sehari-harinya. Setelah dilakukan observasi awal didapatkan hasil pembelajaran lompat dari nilai aspek afektif, untuk aspek kognitif memberikan soal sebanyak 15 butir pilihan ganda, dan aspek psikomotor memberikan video contoh gerakan lompat jauh. Nilai-nilai ini didapatkan dari hasil observasi awal untuk lebih jelasnya dapat dilihat pada Tabel 3.

Tabel 3. Hasil Tes Awal Aspek Afektif

\begin{tabular}{|c|c|c|c|c|}
\hline Nilai & Kategori & Kriteria & Jumlah Siswa & Presentase \\
\hline $81-100$ & Sangat Baik & Tuntas & 5 & $55,5 \%$ \\
\hline $70-80$ & Baik & Tuntas & 4 & $44,5 \%$ \\
\hline $51-69$ & Cukup & Tidak Tuntas & - & - \\
\hline$<50$ & Kurang & Tidak Tuntas & - & - \\
\hline \multicolumn{3}{|c|}{ Jumlah } & 9 & $100 \%$ \\
\hline
\end{tabular}

Berdasarkan data diatas rata-rata nilai siswa adalah 80 dan yang mendapat nilai diatas KKM (70) berjumlah 9 (100\%) siswa kategori tuntas. Pembelajaran lompat jauh di kelas V SDIT Ummul Qurro Sambirejo Sragen pada sikap afektif sudah memncapai ketuntasan.

Tabel 4. Hasil Tes Awal Aspek Kognitif

\begin{tabular}{|c|c|c|c|c|}
\hline Nilai & Kategori & Kriteria & Jumlah Siswa & Presentase \\
\hline $81-100$ & Sangat Baik & Tuntas & - & - \\
\hline $70-80$ & Baik & Tuntas & 3 & $33,3 \%$ \\
\hline $51-69$ & Cukup & Tidak Tuntas & 6 & $66,7 \%$ \\
\hline$<50$ & Kurang & Tidak Tuntas & - & - \\
\hline \multicolumn{3}{|c|}{ Jumlah } & 9 & $100 \%$ \\
\hline
\end{tabular}

Berdasarkan nilai dari tes aspek kognitif pembelajaran lompat jauh dapat dilihat terdapat 3 siswa $(33,3 \%)$ mendapatkan nilai dengan kategori baik, 6 siswa $(66,7 \%)$ mendapatkan nilai dengan kategori cukup. Secara umum siswa dinyatakan belum tuntas pada penilain aspek kognitif dengan capaian $66,7 \%$ siswa dan dengan ratarata nilai siswa 67 sehingga dinyatakan belum tuntas.

Tabel 5. Hasil Tes Awal Aspek Psikomotor

\begin{tabular}{ccccc}
\hline Nilai & Kategori & Kriteria & $\begin{array}{c}\text { Jumlah } \\
\text { Siswa }\end{array}$ & Presentase \\
\hline $81-100$ & Sangat Baik & Tuntas & - & - \\
$70-80$ & Baik & Tuntas & 2 & $22,2 \%$ \\
$51-69$ & Cukup & Tidak Tuntas & 7 & $77,8 \%$ \\
$<50$ & Kurang & Tidak Tuntas & - & - \\
\hline \multicolumn{7}{c}{ Jumlah } & & 9 & $100 \%$ \\
\hline
\end{tabular}

Berdasarkan nilai dari tes aspek psikomotor pembelajaran lompat jauh dapat dilihat terdapat 2 siswa $(22,2 \%)$ mendapatkan nilai dengan kategori baik, 7 siswa 
(77,8\%) mendapatkan nilai dengan kategori cukup. Secara umum siswa dinyatakan belum tuntas pada penilain aspek Psikomotor dengan capaian $77,8 \%$ siswa dan dengan rata-rata nilai siswa 68 sehingga dinyatakan belum tuntas.

Hasil perolehan nilai rata-rata kelas $\mathrm{V}$ pada mata pelajaran lompat jauh aspek afektif sudah sangat baik sehingga tidak diperlukan tes lebih lanjut. Untuk aspek kognitif mendapatkan kategori cukup, pada aspek psikomotor juga mendapatkan kategori cukup. Sehingga pada kedua aspek tersebut aspek kognitif dan psikomotor, perlu mendapatkan tindakan lanjut agar dapat meningkatkan belajar siswa dalam pembelajaran lompat jauh.

\section{Hasil Penelitian Siklus I}

Berdasarkan hasil observasi awal yang dilaksanakan didapatkan bahwa nilai ratarata siswa kelas $\mathrm{V}$ materi lompat jauh masih kurang pada aspek kognitif dan psikomotor sehingga perlu dilakukan tindakan. Berikut merupakan hasil tes pembelajaran lompat jauh menggunakan Software Articulate Storyline 3 setelah tindakan.

Tabel 6. Hasil Tes Siklus I Aspek Kognitif

\begin{tabular}{|c|c|c|c|c|c|c|}
\hline \multirow{2}{*}{ Nilai } & \multirow{2}{*}{ Kategori } & \multirow{2}{*}{ Kriteria } & \multicolumn{2}{|c|}{ Pertemuan I } & \multicolumn{2}{|c|}{ Pertemuan II } \\
\hline & & & Jumlah Siswa & $\%$ & Jumlah Siswa & $\%$ \\
\hline $81-100$ & Sangat Baik & Tuntas & - & - & 4 & $44,4 \%$ \\
\hline $70-80$ & Baik & Tuntas & 3 & $33,3 \%$ & 5 & $55,6 \%$ \\
\hline $51-69$ & Cukup & Tidak Tuntas & 6 & $66,7 \%$ & - & - \\
\hline$<50$ & Kurang & Tidak Tuntas & - & - & - & - \\
\hline \multicolumn{3}{|c|}{ Jumlah } & 9 & $100 \%$ & & $100 \%$ \\
\hline
\end{tabular}

Berdasarkan data hasil tes setelah dilakukan tindakan maka didapatkan nilai pada pertemuan I kategori baik 3 siswa (33,3\%), kategori cukup 6 siswa (66,6\%), dengan nilai rata-rata siswa adalah 66 dan dinyatakan belum memenuhi dari nilai KKM yaitu 70. Sedangkan pada pertemuan II terjadi peningkatan yang baik, kategori sangat baik 4 siswa $(44,4 \%)$, dan kategori sangat baik 5 siswa $(55,5)$, dengan nilai rata-rata 80 dan dinyatakan sudah melebihi dari nilai ketuntasan (KKM) yaitu 70.

Tabel 7. Hasil Tes Siklus I Aspek Psikomotor

\begin{tabular}{ccccccc}
\hline \multirow{2}{*}{ Nilai } & \multirow{2}{*}{ Kategori } & \multirow{2}{*}{ Kriteria } & \multicolumn{2}{c}{ Pertemuan I } & \multicolumn{2}{c}{ Pertemuan II } \\
\cline { 4 - 7 } & & & Jumlah Siswa & $\%$ & Jumlah Siswa & $\%$ \\
\hline $81-100$ & Sangat Baik & Tuntas & - & - & 2 & $22,2 \%$ \\
$70-80$ & Baik & Tuntas & 4 & $44,4 \%$ & 7 & $77,8 \%$ \\
$51-69$ & Cukup & Tidak Tuntas & 5 & $55,6 \%$ & - & - \\
$<50$ & Kurang & Tidak Tuntas & - & - & - & - \\
\hline \multicolumn{3}{c}{ Jumlah } & 9 & $100 \%$ & & $100 \%$ \\
\hline
\end{tabular}

Berdasarkan data hasil tes setelah dilakukan tindakan maka didapatkan nilai pada pertemuan I kategori baik 4 siswa $(44,4 \%)$, kategori cukup 5 siswa $(55,6 \%)$, dengan nilai rata-rata siswa adalah 68 dan dinyatakan belum memenuhi dari nilai KKM yaitu 70. Sedangkan pada pertemuan II terjadi peningkatan yang baik, kategori sangat baik 7 siswa $(77,8 \%)$, dan kategori sangat baik 2 siswa $(22,2 \%)$, 
dengan nilai rata-rata 80 dan dinyatakan sudah melebihi dari nilai ketuntasan (KKM) yaitu 70 .

\section{PEMBAHASAN}

Berdasarkan dari hasil pelaksanaan penelitian tindakan kelas pada siswa kelas $\mathrm{V}$ materi lompat jauh dengan menggunakan Software Articulate Storyline 3 diperoleh hasil pada tes awal sebagai berikut: dari aspek afektif sudah tuntas dalam pelaksanaan pembelajaran lompat jauh. Aspek kognitif terdapat 3 siswa $(33,3 \%)$ mendapatkan nilai dengan kategori baik, 6 siswa $(66,7 \%)$ mendapatkan nilai dengan kategori cukup. Secara umum siswa dinyatakan belum tuntas pada penilain aspek kognitif dengan rata-rata nilai 67. Sedangkan aspek psikomotor terdapat 2 siswa $(22,2 \%)$ mendapatkan nilai dengan kategori baik, 7 siswa $(77,8 \%)$ mendapatkan nilai dengan kategori cukup. Secara umum siswa dinyatakan belum tuntas pada penilain aspek Psikomotor dengan dengan rata-rata nilai siswa 68 sehingga dinyatakan belum tuntas.

Berdasarkan hal tersebut maka dilaksanakan siklus I untuk dapat memperbaiki nilai perolehan dari 9 siswa pada kedua aspek tersebut. Pada siklus I aspek kognitif menunjukkan kenaikan yang baik terutama di sklus I pertemuan II siswa yang mendapatkan kategori "Sangat Baik" sebanyak 4 siswa (44,4\%), sedangankan yang mendapat kategori "Baik" 5 siswa $(55,6 \%)$, secara umum rata-rata siswa mendapatkan nilai 80 dan dinyatakan sudah memenuhi Kriteria Ketuntasan Minimum (KKM). Untuk aspek psikomotor di siklus I pertemuan II siswa yang mendapatkan kategori "Sangat Baik" sebanyak 2 siswa (22,2\%), yang mendapatkan kategori "Baik" sebanyak 7 siswa (77,8\%). Secara umum siswa mendapatkan nilai 80. Maka pada penelitian ini peneliti memutuskan untuk mengentikan penelitian ini karena sudah memenuhi nilai KKM sesuai apa yang diharapkan oleh peneliti.

Hal ini menunjukan adanya peningkatan pada proses pembelajaran lompat jauh menguunakan Software Articulate Storyline 3. Pada penelitian ini peneliti membuktikan bahwa penggunaan Software Articulate Storyline 3 sangat efektif untuk meningkatkan pembelajaran lompat jauh. Hal ini dibuktikan dari peningkatan proses pembelajaran dari aspek afektif, kognitif dan psikomotor.

Pada penelitian sebelumnya yang dilakukan oleh Priono (2021) dengan judul Implementasi Pembelajaran PJOK Pada Masa Pandemi COVID-19 di MTs SeKecamatan Sei Balai Kabupaten Batu Bara Provinsi Sumatera Utara yang menggunakan aplikasi Whatsapp grup sebagai aktifitas pembelajaran daring. Pada penelitian tersebut dismpulkan pelaksanaan pembelajaran daring $100 \%$ guru menggunakan media pembelajaran whatsapp grup, 50\% peserta didik antusias dan berpartisipasi baik dalam pembelajaran. $100 \%$ penilaian berdasarkan pengumpulan tugas dan ujian, $87,5 \%$ guru mengatakan penilaian pembelajaran daring tidak efektif, dan 50\% kendala dalam pembelajaran PJOK daring yaitu kesulitan mengakses internet.

\section{SIMPULAN}

Berdasarkan hasil penelitian di kelas SDIT Ummul Qurro Sambirejo Sragen, penerapan model pembelajaran menggunakan Software Articulate Storyline 3 dapat digunakan dalam meningkatkan proses pembelajaran terlebih pada masa pandemi 
COVID-19 ini dimana proses pembelajaran dilakukan secara daring. Ini dibuktikan dari hasil penelitian yang diperoleh pada siklus I terjadi peningkatan yang sangat baik sesuai yang diharapkan oleh peneliti.

\section{UCAPAN TERIMA KASIH}

Peneliti mengucapkan terimakasih banyak kepada keluarga besar SDIT Ummul Qurro Sambirejo Sragen yang telah memberikan kesempatan bagi peniliti untuk menerapkan model pembelajaran menggunakan Software Articulate Storyline 3. Peneliti juga berterimakasih kepada Bapak Arief Nur Wahyudi dan Bapak Aba Sandi Prayoga sebagai dosen pembimbing yang selalu senantiasa membimbing peneliti agar penelitian ini berjalan dengan baik.

\section{REFERENSI}

Abidin, Z. (2016). Penerapan Pemilihan Media Pembelajaran. Edcomtech, 1(1), 920.

Alwi, S. (2017). Problematika Guru dalam Pengembangan Media Pembelajaran. Itqan, 8(2), 145-167.

Budiman, H. (2017). Peran Teknologi Informasi Dan Komunikasi Dalam Pendidikan. Al-Tadzkiyyah: Jurnal Pendidikan Islam, 8(1), 31-43. https://doi.org/10.24042/atjpi.v8i1.2095

Khasanah, D. R. A. U., Pramudibyanto, H., \& Widuroyekti, B. (2020). Pendidikan Dalam Masa Pandemi COVID-19. Jurnal Sinestesia, 10(1), 41-48.

Kuswanto, J., \& Radiansah, F. (2018). Media Pembelajaran Berbasis Android Pada Mata Pelajaran Sistem Operasi Jaringan Kelas XI. Jurnal Media Infotama, 14(1), 15-20. https://doi.org/10.37676/jmi.v14i1.467

Muzakir, U. (2013). Manajemen Peningkatan Mutu Pendidikan Tinggi. Visipena, 4(2), 130-145. https://doi.org/10.46244/visipena.v4i2.218

Priono, J., \& Siregar, I. (2021). Implementasi Pembelajaran Pjok Pada Masa Pandemi COVID-19 Di Mts Se-Kecamatan Sei Balai Kabupaten Batu Bara Provinsi Sumatera Utara Jurnal Penjaskesrek. 8(1), 32-45. https://doi.org/10.46244/penjaskesrek.v8i1.1367

Risalah, A., Ibad, W., Maghfiroh, L., Azza, M. I., Cahyani, S. A., \& Ulfayati, Z. A. (2020). Dampak pandemi COVID-19 terhadap kegiatan belajar mengajar di MI/SD (studi $\mathrm{kbm}$ berbasis daring bagi guru dan siswa). JIEES: Journal of Islamic Education at Elementary School, 1(1), 10-16. https://doi.org/10.47400/jiees.v1i1.5

Salwani, R., \& Ariani, Y. (2021). Pengembangan Media Pembelajaran Tema 3 Subtema 3 Berbasis Articulate Storyline 3 di Kelas Va SDIT Mutiara Kota Pariaman. Jurnal Pendidikan Tambusai, 5(1), 409-415. https://doi.org/10.31004/jptam.v5i1.963

Setiawan, D. (2018). Dampak perkembangan teknologi informasi dan komunikasi terhadap budaya. Jurnal Simbolika: Research and Learning in Communication Study, 4(1), 62-72. https://doi.org/10.31289/simbollika.v4i1.1474 